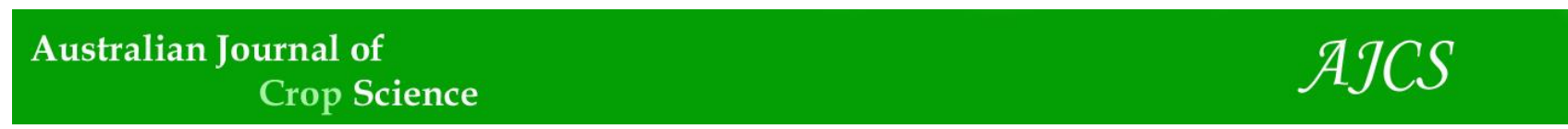

AJCS 10(6):864-873 (2016)

ISSN:1835-2707

DOI: $10.21475 /$ ajcs.2016.10.06.p7568

\title{
Forage sward structure of Mulato grass (Brachiaria hybrid ssp.) subjected to rotational stocking strategies
}

Márcia Cristina Teixeira da Silveira ${ }^{1^{*}}$, Domicio do Nascimento Júnior ${ }^{2}$, Carlindo Santos Rodrigues ${ }^{3}$, Karine da Silva Pena ${ }^{2}$, Salim Jacaúna de Souza Júnior ${ }^{4}$, Leandro Martins Barbero ${ }^{5}$, Veridiana Aparecida Limão ${ }^{5}$, Valéria Pacheco Batista Euclides ${ }^{6}$, Sila Carneiro da Silva ${ }^{7}$

${ }^{1}$ CPPSUL - Embrapa Southern Region Animal Husbandry, Rodovia BR 153, km 632,9- Vila Industrial - 96401970 - Bagé, RS - Brazil

${ }^{2}$ UFV - Dept. of Animal Science, Av. P.H. Rolfs, s/n., - Campus Universitário - 36570-000 - Viçosa, MG - Brazil

${ }^{3}$ IF Baiano - Dean of Research, Innovation and Graduate Studies - Rua do Rouxinol, 115, 41720-052 - Campus

Imbuí, Ba - Brazil

${ }^{4}$ UFPA - Faculty of Agronomy, Rua Coronel José Porfírio, 2515, 68372-040 - Altamira, PA - Brazil

${ }^{5}$ UFU - Dept. of Animal Science, Av. Ceará, s/n., - Campus Umuarama - bloco 2T, 38400-902 - Uberlândia - MG, Brazil

${ }^{6}$ CNPGC - Embrapa Beef Cattle, BR 262, km 4 - C.P. 154 - 79002-970 - Campo Grande, MS - Brazil

${ }^{7}$ USP/ESALQ - Dept. of Animal Science, Av. Pádua Dias, n. 11 - 13418-900 - Piracicaba, SP - Brazil

*Corresponding author: marcia.c.silveira@embrapa.br

\begin{abstract}
The pasture structure is the point of origin and convergence of plants and grazing animal responses, which makes its knowledge essential in the planning of grazing management strategies. The objective of this study was to evaluate and describe the variation in sward structure of mulato grass subjected to stocking strategies. The treatments corresponded to combinations between the postgrazing height $\left(15\right.$ and $20 \mathrm{~cm}$ ) and the pre-grazing targets $\left(95 \%\right.$ and maximum light interception during regrowth: $\mathrm{LI}_{95 \%}$ and $\left.\mathrm{LI}_{\mathrm{Max}}\right)$. Sward height, light interception, forage mass, morphological composition, and vertical structure were evaluated. There was no difficulty maintaining the set post-grazing heights in the pastures managed with the $\mathrm{LI}_{95 \%}$ target, which was not observed in the pastures managed with the $\mathrm{LI}_{\mathrm{Max}}$ target, especially for the post-grazing of $15 \mathrm{~cm}$. For pre-grazing, the $\mathrm{LI}_{95 \%}$ and $\mathrm{LI}_{\mathrm{Max}}$ targets corresponded to the heights of 30 and $40 \mathrm{~cm}$, respectively. Overall, the pastures managed with the $\mathrm{LI}_{95 \%}$ target showed a lower height and a lower forage mass with a greater percentage of leaves pre-grazing. For post-grazing, the pastures managed with the $\mathrm{LI}_{95 \%}$ target displayed a greater light interception and a lower forage mass with a higher percentage of leaves, as well as a lower percentage of dead material than the pastures managed under the $\mathrm{LI}_{\mathrm{Max}}$. Based on the results, we conclude that grazing performed according to the $\mathrm{LI}_{95 \%}$ pre-grazing target $(30 \mathrm{~cm})$, irrespective of the adopted post-grazing height $(15 \mathrm{or} 20-\mathrm{cm})$, resulted in adequate control of the sward structure, and this management strategy provides good pasture growth with important features for maximum forage intake and nutrients by grazing animals.
\end{abstract}

Keywords: Brachiaria spp., grazing management, light interception, tropical pastures, sward condition, sward height.

Abbreviations: LI_light interception; $\mathrm{LI}_{95 \% \_} 95 \%$ light interception during regrowth; $\mathrm{LI}_{\text {Max_maximum light interception during }}$ regrowth; $\mathrm{LI}_{95 \% / 15 \_} \mathbf{9 5 \%}$ light interception and $15 \mathrm{~cm}$ post-grazing height; $\mathrm{LI}_{95 \% / 20 \_} 95 \%$ light interception and $20 \mathrm{~cm}$ post-grazing height; $\mathrm{LI}_{\mathrm{Max} / 15 \_}$maximum light interception and $15 \mathrm{~cm}$ post-grazing height; $\mathrm{LI}_{\mathrm{Max} / 20 \_}$maximum light interception and $20 \mathrm{~cm}$ postgrazing height.

\section{Introduction}

The forage sward structure is the product of the growth dynamics resulting from the partition and allocation of photoassimilate by forage plants. These define the morphogenesis that regulated by environmental (e.g., water, light, and nutrients) and management factors, which determines the structural characteristics of individual plants and of the plant population in the area. Fonseca et al. (2012) suggested a need for changes in grazing management studies so that controlling the grazing process could be based on the forage sward structure with the goal of achieving maximum forage and nutrient intake by grazing animals. Thus, for every forage plant being used in the production system, it is important to identify the appropriate "sward condition" (e.g. sward canopy height, forage mass, forage density and residual height) for the animal's entry into and exit from the pasture under intermittent stocking conditions so that the optimal condition at which continuous stocked pastures should be maintained may be determined (Da Silva et al., 2015). For several tropical forage grasses under rotational stocking, the ideal condition of animal entry into the paddocks is indicated as that in which $95 \%$ of the light is intercepted by the forage sward during regrowth (Da Silva et al., 2009; Euclides et al., 2015). This condition is associated with a greater accumulation of leaves and forage intake, 
resulting in better animal performance (Da Silva and Carvalho 2005; Euclides et al., 2015). This 95\% light interception condition is correlated positively with sward canopy height, which allows for the definition of practical management guides for each forage plant - the management goals or targets (Da Silva et al., 2015).

Mulato grass is a promising hybrid of Brachiaria (Brachiaria ruziziensis and Brachiaria brizantha) that was released in 2003 (Silveira et al., 2013). It has great potential for the production of good-quality forage, but it is necessary to define the management goals or targets that incorporate the dynamics of growth and production so that the best productive potential may be explored. Before this context, the objective of this study was to characterise and describe the sward structure of mulato grass subjected to rotational stocking strategies and its variation throughout the year to define management targets for this forage.

\section{Results}

\section{Grazing interval and number of grazing cycles}

The grazing interval was influenced by the time of the seasons $\times$ the light interception pre-grazing $\times$ the postgrazing height $(p=0.0441)$ interaction. Except for late spring, treatment $\mathrm{LI}_{\mathrm{Max} / 15}$ resulted in longer grazing intervals than treatment $\mathrm{LI}_{95 \% / 15}$. Overall, treatment $\mathrm{LI}_{\mathrm{Max} / 20}$ showed a longer grazing interval than treatment $\mathrm{LI}_{95 \% / 20}$ over the entire experimental period (Table 1). Regarding the effect of postgrazing height, differences were observed for the $\mathrm{LI}_{95 \%}$ target only in the summer of 2008, with longer intervals recorded for the $15 \mathrm{~cm}$ height compared with $20 \mathrm{~cm}$. For the $\mathrm{LI}_{\mathrm{Max}}$ target, longer grazing intervals were recorded for the $15 \mathrm{~cm}$ height compared with $20 \mathrm{~cm}$, except in the fall-winter-early spring and late spring.

Treatment $\mathrm{LI}_{95 \% / 20}$ resulted in the largest number of grazing cycles, while the $\mathrm{LI}_{\mathrm{Max} / 15}$ resulted in the lowest number (Table 2). Over the year, a larger number of grazing cycles occurred during the summer (2008 and 2009) compared with the other seasons of the year.

\section{Post and pre-grazing height}

Because it is a control-variable, post-grazing height is only presented descriptively (Figure 3). In the pastures managed with the $\mathrm{LI}_{95 \%}$ target, the obtained values were very close to the intended targets $(15$ and $20 \mathrm{~cm})$. In the pastures managed under the $\mathrm{LI}_{\mathrm{Max}}$, it was not possible to achieve the $15 \mathrm{~cm}$ target throughout the experimental period, and the postgrazing height increased in relation to that intended as the grazing cycles passed. In this case, values of approximately $19 \mathrm{~cm}$ were recorded from the third grazing cycle. The average post-grazing height of the pastures subjected to treatment $\mathrm{LI}_{\mathrm{Max} / 20}$, despite being above the planned target, was more uniform than that achieved in the pastures subjected to treatment $\mathrm{LI}_{\mathrm{Max} / 15}$.

The pre-grazing height varied with the time of the seasons $x$ the light interception pre-grazing $x$ the post-grazing height $(p=0.0448)$ interaction. Pastures subjected to treatment $\mathrm{LI}_{\mathrm{Max} / 15}$ showed, in all seasons of the year, a greater pregrazing height than those subjected to treatment $\mathrm{LI}_{95 \% / 15}$. This same response was observed in the pastures subjected to treatment $\mathrm{LI}_{\mathrm{Max} / 20}$ compared with those subjected to treatment $\mathrm{LI}_{95 \% / 20}$ (Table 3). In the summer of 2008 and in the fallwinter-early spring, there was no difference in the pregrazing height between the post-grazing height targets evaluated at each level of light interception. In the late spring, the pastures managed with the $\mathrm{LI}_{95 \%}$ target showed similar heights as both of the post-grazing targets. However, the pastures managed with the $\mathrm{LI}_{\mathrm{Max}}$ target had a greater pregrazing height when the post-grazing height was $20 \mathrm{~cm}$ relative to $15 \mathrm{~cm}$. In the summer of 2009, for both the LI pregrazing targets, greater pre-grazing height values were observed in the pastures managed with the target of a $20 \mathrm{~cm}$ post-grazing height.

\section{Light interception by the forage sward post- and pre- grazing}

The interception of light by the forage sward post-grazing varied with the seasons $\times$ the light interception pre-grazing $\times$ the post-grazing height $(p=0.0055)$ interaction. Overall, the pastures managed with the $\mathrm{LI}_{\mathrm{Max}}$ target showed lower LI values post-grazing than the pastures managed with the $\mathrm{LI}_{95 \%}$ target, irrespective of the post-grazing height evaluated during the entire experiment. The only exception occurred in the summer of 2009 , which was the time when the pastures subjected to treatment $\mathrm{LI}_{\mathrm{Max} / 20}$ showed similar values to those of the pastures subjected to treatment $\mathrm{LI}_{95 \% / 20}$ (Table 4). In the pastures managed with the $\mathrm{LI}_{\mathrm{Max}}$ target, a greater postgrazing LI was recorded for the post-grazing height of $20 \mathrm{~cm}$ in all seasons of the year. In the pastures managed with the $\mathrm{LI}_{95 \%}$ target, this occurred only in the summer of 2009 , with no differences in the post-grazing height targets in the other seasons of the year.

Light interception by the forage sward pre-grazing was the control variable adopted to indicate the time to interrupt the pastures' regrowth process. Thus, it was not subjected to an analysis of variance. The mean light-interception values achieved during the experimental period for the $\mathrm{LI}_{95 \%}$ target remained very close to what was planned $(95.07 \pm 0.05$ $\mathrm{SEM}$ ). For the $\mathrm{LI}_{\mathrm{Max}}$ target, the obtained values were approximately $99 \%$ during the entire experimental period $(99.17 \pm 0.06 \mathrm{SEM})$

Vertical distribution of the morphological components and forage mass in post- and pre-grazing

In terms of the vertical distribution of the morphological components, the pastures managed with the $\mathrm{LI}_{95 \%}$ showed a greater proportion of leaves from the upper half of the forage sward relative to those managed with the $\mathrm{LI}_{\mathrm{Max}}$ target (corresponding to $40 \mathrm{~cm}$ ). In these, stems and dead material were present in the upper strata at both pre- and post-grazing (Figure 4).

The post-grazing forage mass varied with the post-grazing height $(p<0.0001)$ and the season $\times$ the light interception pre-grazing interaction $(p=0.0004)$. Overall, higher values were recorded for the pastures managed with a post-grazing height of $20 \mathrm{~cm}$ compared with those managed at $15 \mathrm{~cm}$ $\left(5270 \mathrm{vs} 4780 \mathrm{~kg} \mathrm{ha}^{-1} \mathrm{DM} \pm 51\right.$ SEM) during the entire experimental period. Except for the summer of 2008, the pastures managed with the $\mathrm{LI}_{\mathrm{Max}}$ target showed higher forage mass values post-grazing than the pastures managed with the $\mathrm{LI}_{95 \%}$ target. The highest and lowest values of the forage mass post-grazing were recorded in the fall-winter-early spring and the summer, respectively (Table 5).

The percentage of leaves and stems in the forage mass postgrazing varied with the light interception pre-grazing ( $p=$ 0.0014 and 0.0009) and with the season $(p=0.0001$ and 0.0023 , respectively). In general, the pastures managed with the $\mathrm{LI}_{95 \%}$ target had a greater percentage of leaves and a lower percentage of stems than the pastures managed under $\mathrm{LI}_{\text {Max }}$ (Table 5). Higher percentages of leaves were recorded in the summer (2008 and 2009), lower values in the fallwinter-early spring, and intermediate values in the late 
Table 1. Grazing interval (days) in mulato grass pastures subjected to rotational stocking strategies from January 2008 to March 2009.

\begin{tabular}{llc}
\hline \multirow{2}{*}{ Post-grazing height $(\mathrm{cm})$} & \multicolumn{2}{c}{ Light interception $(\%)$} \\
\cline { 2 - 3 } & $\mathrm{LI}_{95 \%}$ & $\mathrm{LI}_{\mathrm{Max}}$ \\
\hline Summer 2008 $(\mathrm{SEM}=1.27)$ & $24 \mathrm{Ba}$ & $31 \mathrm{Aa}$ \\
15 & $17 \mathrm{Bb}$ & $26 \mathrm{Ab}$ \\
20 & & \\
Fall-winter-early spring $(\mathrm{SEM}=11.78)$ & $175 \mathrm{Ba}$ & $228 \mathrm{Aa}$ \\
15 & $174 \mathrm{Ba}$ & $220 \mathrm{Aa}$ \\
20 & & \\
Late spring $(\mathrm{SEM}=1.84)$ & $46 \mathrm{Aa}$ & $49 \mathrm{Aa}$ \\
15 & $45 \mathrm{Aa}$ & $48 \mathrm{Aa}$ \\
20 & & \\
Summer 2009 $(\mathrm{SEM}=2.28)$ & $19 \mathrm{Ba}$ & $46 \mathrm{Aa}$ \\
15 & $17 \mathrm{Ba}$ & $37 \mathrm{Ab}$ \\
20 & &
\end{tabular}

Summer 2008 = January 1st to March 31, 2008; fall-winter-early spring = April 1st to November 15, 2008; late spring = November 16 to December 31, 2008; and summer 2009 = January 1st to March 31, 2009. Treatment means (LI/residual height) within the time of year followed by the same uppercase letter in the rows, and the lowercase letter in the columns do not differ $(p>0.05)$. The values in parentheses correspond to the standard error of the mean.

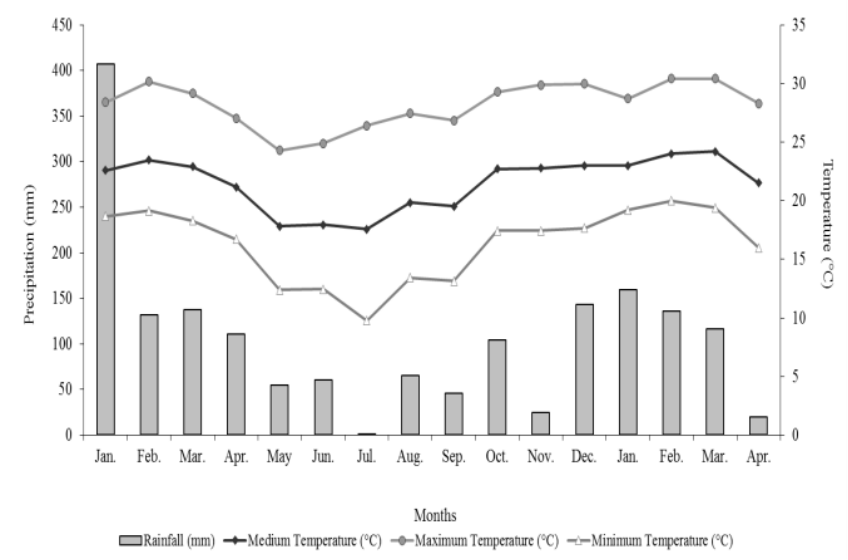

Fig 1. Monthly mean values of the average, maximum, and minimum temperatures and precipitation in the experimental area from January 2008 to April 2009.

Table 2. Total number of grazing cycles performed from January 2008 to March 2009 in mulato grass pastures subjected to rotational stocking strategies

\begin{tabular}{lcccc}
\hline \multirow{2}{*}{ Time of the year } & \multicolumn{4}{c}{ Treatment } \\
\cline { 2 - 5 } & $\mathrm{LI}_{95 \% / 15}$ & $\mathrm{LI}_{95 \% / 20}$ & $\mathrm{LI}_{\mathrm{Max} / 15}$ & $\mathrm{LI}_{\mathrm{Max} / 20}$ \\
\hline Summer 2008 & 11 & 16 & 6 & 8 \\
Fall-winter-early spring & 5 & 6 & 4 & 5 \\
Late spring & 4 & 4 & 4 & 4 \\
Summer 2009 & 18 & 19 & 6 & 8 \\
\hline
\end{tabular}

Summer 2008 = January 1st to March 31, 2008; fall-winter-early spring = April 1st to November 15, 2008; late spring = November 16 to December 31, 2008; and summer 2009 = January 1 st to March 31, 2009. Treatment (LI/residual height)

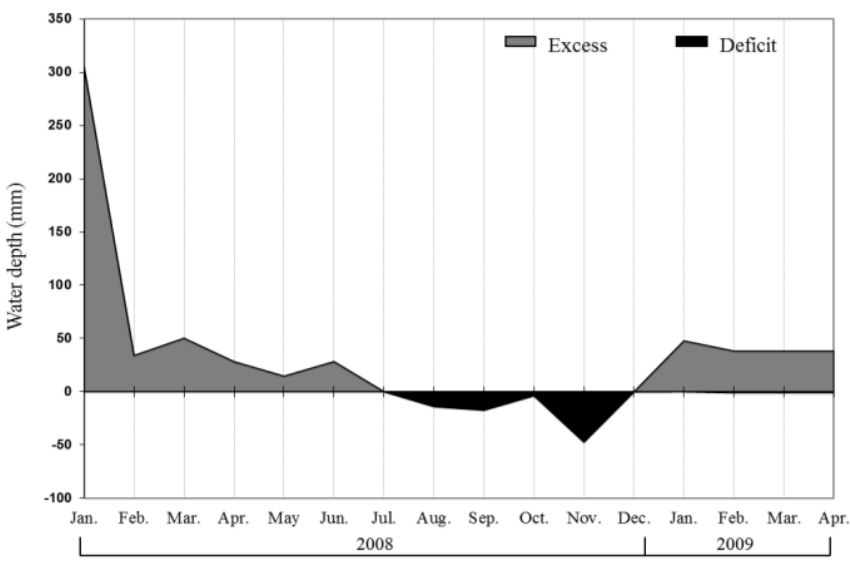

Fig 2. Monthly water balance in the experimental area from January 2008 to April 2009. 
Table 3. Pre-grazing height (cm) of mulato grass subjected to rotational stocking strategies from January 2008 to March 2009.

\begin{tabular}{lcc}
\hline \multirow{2}{*}{ Post-grazing height $(\mathrm{cm})$} & \multicolumn{2}{c}{ Light interception } \\
\cline { 2 - 3 } & LI $_{95 \%}$ & $\mathrm{LI}_{\mathrm{Max}}$ \\
15 & $\mathrm{Summer} 2008(\mathrm{SEM}=0.57)$ & $37.6 \mathrm{Aa}$ \\
20 & $27.6 \mathrm{Ba}$ & $37.3 \mathrm{Aa}$ \\
& $27.7 \mathrm{Ba}$ & $43.0 \mathrm{Aa}$ \\
15 & Fall-winter-early spring $(\mathrm{SEM}=0.70)$ \\
20 & $29.9 \mathrm{Ba}$ & $41.3 \mathrm{Aa}$ \\
& $31.4 \mathrm{Ba}$ & $41.8 \mathrm{Ab}$ \\
15 & $\mathrm{Late}$ spring $(\mathrm{SEM}=0.55)$ \\
20 & $30.2 \mathrm{Ba}$ & $43.7 \mathrm{Aa}$ \\
& $30.7 \mathrm{Ba}$ & $40.9 \mathrm{Ab}$ \\
15 & $\mathrm{Summer} 2009(\mathrm{SEM}=0.34)$ \\
20 & $27.7 \mathrm{Bb}$ & $44.5 \mathrm{Aa}$ \\
\hline Mean & $29.7 \mathrm{Ba}$ & $41.3 \mathrm{~A}$ \\
\hline
\end{tabular}

Summer 2008 = January 1st to March 31, 2008; fall-winter-early spring = April 1st to November 15, 2008; late spring = November 16 to December 31, 2008; and summer 2009 = January 1st to March 31, 2009. Treatment means (LI/residual height) within the time of year followed by the same uppercase letter in the rows, and the lowercase letter in the columns do not differ $(p>0.05)$. The values in parentheses correspond to the standard error of the mean.

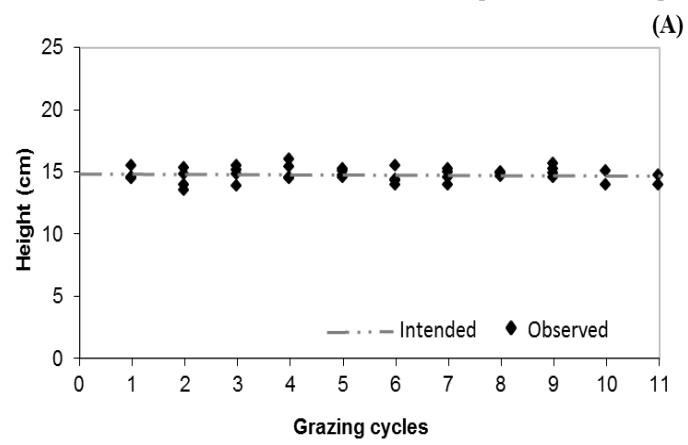

$$
\text { (A) }
$$
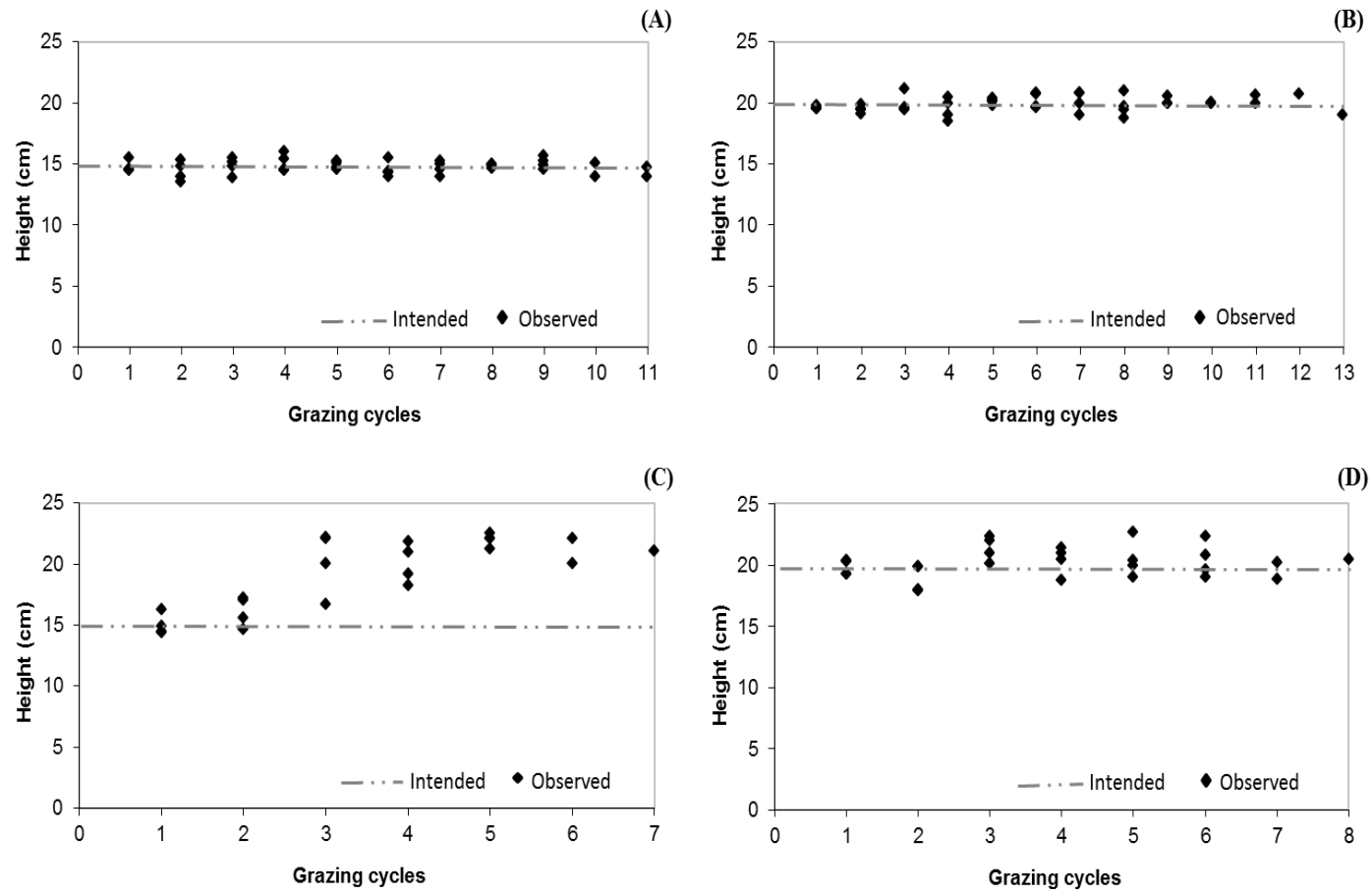

Fig 3. Post-grazing heights of mulato grass subjected to rotational stocking strategies from January 2008 to March 2009. Treatment (LI/ post-grazing height): (A) $\mathrm{LI}_{95 \% / 15}$, (B) $\mathrm{LI}_{95 \% / 20}$, (C) $\mathrm{LI}_{\mathrm{Max} / 15}$ and (D) $\mathrm{LI}_{\mathrm{Max} / 20}$.

spring. The percentage of stems showed a similar variation pattern only without differences between the fall-winter-early spring and the late spring. The percentage of dead material in the forage mass post-grazing varied with the time of the year $\times$ the light interception pre-grazing interaction $(p=0.0010)$. In the fall-winter-early spring and the summer of 2009, the pastures managed with the $\mathrm{LI}_{\mathrm{Max}}$ target showed a higher percentage of dead material than the pastures managed with the $\mathrm{LI}_{95 \%}$ target. There was no difference between the pregrazing LI targets in the summer of 2008 and the late spring. In general, higher percentages of dead material were recorded in the fall-winter-early spring, lower values in the summer, and intermediate values in the late spring for both of the LI targets evaluated (Table 5).

\section{Forage mass post- and pre-grazing management}

The pre-grazing forage mass varied with the post-grazing height $(p=0.0068)$ and with the season $\times$ the light interception pre-grazing interaction $(p=0.0162)$. In general, lower values were found in the pastures managed with a postgrazing height of $15 \mathrm{~cm}$ relative to those managed at $20 \mathrm{~cm}$ (7200 vs $7650 \mathrm{~kg} \mathrm{ha}^{-1} \mathrm{DM} \pm 108$ SEM) during the entire experimental period. The pastures managed with the $\mathrm{LI}_{95 \%}$ target showed a lower forage mass pre-grazing compared to those managed under $\mathrm{LI}_{\mathrm{Max}}$ in all seasons of the year. The forage mass of the pastures increased from the summer of 2008 to the fall-winter-early spring, followed by a reduction in the late spring and the summer of 2009. Despite the similar pattern of variation over the year, the reduction of the pastures managed with the $\mathrm{LI}_{\mathrm{Max}}$ target was about three times lower than that in the pastures managed with the $\mathrm{LI}_{95 \%}$ target, which caused the forage mass pre-grazing of these pastures to be greater than that at the start of the experiment and did not occur in the pastures managed with the $\mathrm{LI}_{95 \%}$ target.

The percentage of leaves and stems pre-grazing varied with the light interception pre-grazing $(p<0.0001$ and 0.0071 , respectively) and with the season $(p<0.0001$ for both 
Table 4. Light interception post-grazing (\%) in mulato grass pastures subjected to rotational stocking strategies from January 2008 to March 2009.

\begin{tabular}{lcc}
\hline \multirow{2}{*}{ Post-grazing height $(\mathrm{cm})$} & \multicolumn{2}{c}{ Light interception } \\
\cline { 2 - 3 } & LI $_{95 \%}$ & LI $_{\mathrm{Max}}$ \\
\hline & Summer $2008(\mathrm{SEM}=0.91)$ & \\
20 & $78.2 \mathrm{Ab}$ & $71.5 \mathrm{Bb}$ \\
& $84.4 \mathrm{Aa}$ & $80.7 \mathrm{Ba}$ \\
15 & Fall-winter-early spring $(\mathrm{SEM}=1.98)$ \\
20 & $80.6 \mathrm{Aa}$ & $65.1 \mathrm{Bb}$ \\
& $84.6 \mathrm{Aa}$ & $71.8 \mathrm{Ba}$ \\
15 & Late spring (SEM = 1.08) & \\
20 & $83.6 \mathrm{Aa}$ & $64.7 \mathrm{Bb}$ \\
& $86.1 \mathrm{Aa}$ & $81.3 \mathrm{Ba}$ \\
15 & Summer 2009 (SEM = 1.68) & \\
20 & $79.7 \mathrm{Aa}$ & $66.0 \mathrm{Bb}$ \\
\hline
\end{tabular}

Summer 2008 = January 1st to March 31, 2008; fall-winter-early spring = April 1st to November 15, 2008; late spring = November 16 to December 31 , 2008; and summer 2009 = January 1st to March 31, 2009. Treatment means (LI/residual height) within the time of year followed by the same uppercase letter in the rows, and the lowercase letter in the columns do not differ $(p>0.05)$. The values in parentheses correspond to the standard error of the mean.

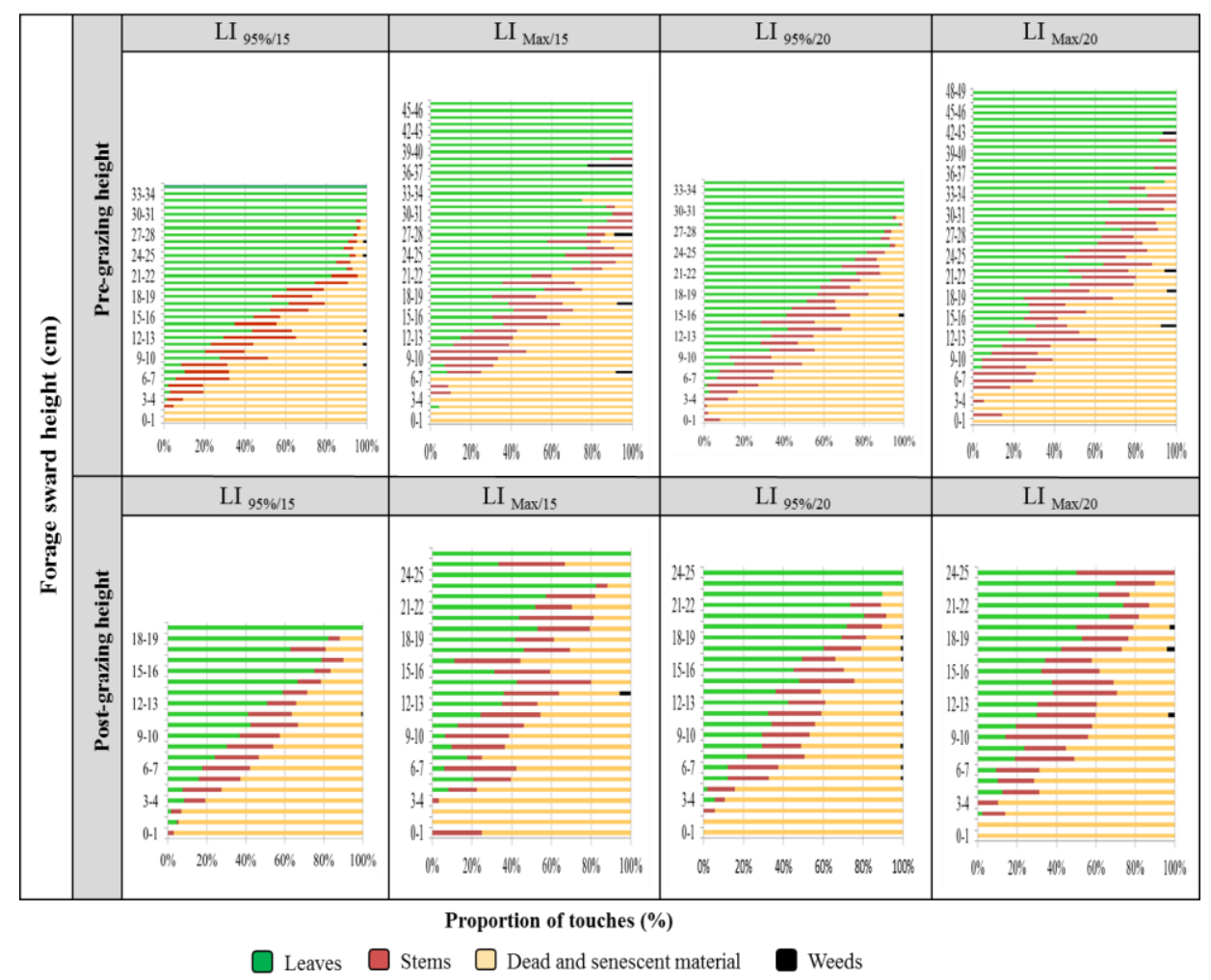

Fig 4. Spatial distribution of the morphological components over the vertical profile of the sward of mulato grass subjected to rotational stocking strategies in the summer of 2009.

variables). The percentage of dead material varied only with season $(p=0.0001)$. Overall, the pastures managed with a target of $\mathrm{LI}_{95 \%}$ had a higher percentage of leaves and a lower percentage of stems than the pastures managed with the $\mathrm{LI}_{\mathrm{Max}}$ target. Throughout the experiment, a greater percentage of leaves were recorded in the summer of 2009 , and the lowest was found in the fall-winter-early spring with intermediate values in the other times of the year. For the stems, higher values were recorded in the summers of 2008 and 2009 and lower ones in the fall-winter-early spring. The dead material showed the opposite response, i.e., higher values in the fallwinter-early spring and lower numbers in the summers of 2008 and 2009, and intermediate values in the late spring (Table 6).

\section{Discussion}

To understand changes that occur in the function of forage plants under grazing, experimental protocols have been adopted to keep them in stable conditions within the planned contrasts of utilization. In these protocols, for the cases of intermittent stocking (e.g., rotational stocking), the light intercepted by the sward during regrowth was employed as a means to determine the ideal grazing interval. Its association with different post-grazing heights, corresponding to the levels of defoliation intensities, makes it possible to generate the contrasting defoliation regimes necessary to evaluate the behaviour and plasticity of forage plants over different seasons of the year. 
Table 5. Forage mass and percentage of leaves, stems and dead material post-grazing in mulato grass subjected to rotational stocking strategies during the regrowth.

\begin{tabular}{|c|c|c|c|}
\hline \multicolumn{4}{|c|}{ Forage mass $\left(\mathrm{kg} \mathrm{ha}^{-1} \mathrm{DM}\right)$} \\
\hline \multirow{2}{*}{ Time of the year } & \multicolumn{3}{|c|}{ Light interception } \\
\hline & $\mathrm{LI}_{95 \%}$ & $\mathrm{LI}_{\mathrm{Max}}$ & Mean \\
\hline Summer 2008 & $4290 \mathrm{Ab}$ & $4500 \mathrm{Ad}$ & 4400 \\
\hline Fall-winter-early spring & $\begin{array}{l}5390 \mathrm{Ba} \\
(183)\end{array}$ & $\begin{array}{l}6690 \mathrm{Aa} \\
(183)\end{array}$ & $\begin{array}{l}6040 \\
(129)\end{array}$ \\
\hline Late spring & $\begin{array}{l}4390 \mathrm{Bb} \\
(184)\end{array}$ & $\begin{array}{l}5980 \mathrm{Ab} \\
(184)\end{array}$ & $\begin{array}{l}5185 \\
(130)\end{array}$ \\
\hline Summer 2009 & $\begin{array}{l}3520 \mathrm{Bc} \\
(129)\end{array}$ & $\begin{array}{l}5400 \mathrm{Ac} \\
(129)\end{array}$ & $\begin{array}{l}4460 \\
(91)\end{array}$ \\
\hline Mean & $\begin{array}{l}4400 \mathrm{~B} \\
(51)\end{array}$ & $\begin{array}{l}5640 \mathrm{~A} \\
(51)\end{array}$ & \\
\hline \multicolumn{4}{|l|}{ Leaves $(\%)$} \\
\hline Summer 2008 & $\begin{array}{l}31.4 \\
(1.83)\end{array}$ & $\begin{array}{l}22.3 \\
(1.83)\end{array}$ & $\begin{array}{l}26.9 \mathrm{a} \\
(1.55)\end{array}$ \\
\hline Fall-winter-early spring & $\begin{array}{l}19.9 \\
(1.83)\end{array}$ & $\begin{array}{l}15.0 \\
(1.83)\end{array}$ & $\begin{array}{l}17.4 \mathrm{c} \\
(0.95)\end{array}$ \\
\hline Late spring & $\begin{array}{l}25.9 \\
(1.83)\end{array}$ & $\begin{array}{l}17.9 \\
(1.83)\end{array}$ & $\begin{array}{l}21.9 \mathrm{~b} \\
(1.26)\end{array}$ \\
\hline Summer 2009 & $\begin{array}{l}31.1 \\
(1.83)\end{array}$ & $\begin{array}{l}17.9 \\
(1.83)\end{array}$ & $\begin{array}{l}24.5 \mathrm{ab} \\
(2.02)\end{array}$ \\
\hline Mean & $\begin{array}{l}27.1 \mathrm{a} \\
(1.43)\end{array}$ & $\begin{array}{l}18.3 \mathrm{~b} \\
(1.43)\end{array}$ & \\
\hline \multicolumn{4}{|l|}{ Stems $(\%)$} \\
\hline Summer 2008 & $\begin{array}{l}32.0 \\
(0.81)\end{array}$ & $\begin{array}{l}36.8 \\
(0.81)\end{array}$ & $\begin{array}{l}34.4 \mathrm{a} \\
(0.60)\end{array}$ \\
\hline Fall-winter-early spring & $\begin{array}{l}23.7 \\
(2.48)\end{array}$ & $\begin{array}{l}35.2 \\
(2.48)\end{array}$ & $\begin{array}{l}29.5 \mathrm{~b} \\
(1.70)\end{array}$ \\
\hline Late spring & $\begin{array}{l}26.2 \\
(1.70)\end{array}$ & $\begin{array}{l}32.5 \\
(1.70)\end{array}$ & $\begin{array}{l}29.4 \mathrm{~b} \\
(1.15)\end{array}$ \\
\hline Summer 2009 & $\begin{array}{l}32.8 \\
(1.00)\end{array}$ & $\begin{array}{l}34.1 \\
(1.00)\end{array}$ & $\begin{array}{l}33.5 \mathrm{a} \\
(0.73)\end{array}$ \\
\hline Mean & $\begin{array}{l}28.7 \mathrm{~b} \\
(0.90)\end{array}$ & $\begin{array}{l}34.7 \mathrm{a} \\
(0.90)\end{array}$ & \\
\hline \multicolumn{4}{|l|}{ Dead material $(\%)$} \\
\hline Summer 2008 & $\begin{array}{l}36.3 \mathrm{Ac} \\
(2.16)\end{array}$ & $\begin{array}{l}40.6 \mathrm{Ac} \\
(2.16)\end{array}$ & $\begin{array}{l}38.45 \\
(1.53)\end{array}$ \\
\hline Fall-winter-early spring & $\begin{array}{l}49.6 \mathrm{Ba} \\
(2.16)\end{array}$ & $\begin{array}{l}57.4 \mathrm{Aa} \\
(2.16)\end{array}$ & $\begin{array}{l}53.50 \\
(1.53)\end{array}$ \\
\hline Late spring & $\begin{array}{l}47.5 \mathrm{Ab} \\
(2.16)\end{array}$ & $\begin{array}{l}47.7 \mathrm{Ab} \\
(2.16)\end{array}$ & $\begin{array}{l}47.60 \\
(1.53)\end{array}$ \\
\hline Summer 2009 & $\begin{array}{l}35.5 \mathrm{Bc} \\
(2.16)\end{array}$ & $\begin{array}{l}46.5 \mathrm{Ab} \\
(2.16)\end{array}$ & $\begin{array}{l}41.0 \\
(1.53)\end{array}$ \\
\hline Mean & $\begin{array}{l}42.2 \\
(1.08) \\
\end{array}$ & $\begin{array}{l}46.1 \\
(1.08)\end{array}$ & \\
\hline
\end{tabular}

Summer 2008 = January 1st to March 31, 2008; fall-winter-early spring = April 1st to November 15, 2008; late spring = November 16 to December 31 , 2008; and summer Summer 2008 = January 1st to March 31, 2008; fall-winter-early spring = April lst to November 15, 2008; late spring = November 16 to December 31,2008 ; and s
2009 = January 1 st to March 31, 2009. The means followed by the same uppercase letter in the rows, and the lowercase letter in the columns do not differ $(p>0.05$. The values in parentheses correspond to the standard error of the mean.

In the case of mulato grass, the forage mass, its morphological composition, the post-grazing height, the vertical structure, and the LI post-grazing were highly influenced by the seasons of the year and by the evaluated management strategies $\left(\mathrm{LI}_{95 \% / 15} ; \mathrm{LI}_{95 \% / 20} ; \mathrm{LI}_{\mathrm{Max} / 15} ;\right.$ and $\mathrm{LI}_{\mathrm{Max} / 20}$ ), especially the frequency at which grazing was performed. The season of the year affected practically all of the variables in a common pattern, indicating the strong influence of this factor, whose variations were at the speed and magnitude of the response. According to Bircham and Hodgson (1983), the structure of the forage sward is the result of conflicting processes, i.e., the grazing and growth of forage plants, as plants are not passive in the defoliation process. Among the structural traits, height has the most consistent relationship with the responses from both plants and animals and with responses related to the accumulation of forage during the entire year and in any climatic condition (Hodgson and Maxwell, 1981). In this context, height is considered a connection between the sward structure and the processes of interception of the incident light, allowing for the determination of practical of pasture-management guides. In the present study, the $\mathrm{LI}_{95 \%}$ and $\mathrm{LI}_{\mathrm{Max}}$ targets corresponded to the pre-grazing heights of 30 and $40 \mathrm{~cm}$, respectively (Table 3). These values remained stable, irrespective of the post-grazing height utilized, which stresses the importance of using the light interception associated with the forage sward height as a management target. The $\mathrm{LI}_{\mathrm{Max}}$ target resulted in longer intervals and in a smaller number of grazing cycles (Tables 1 and 2). The longer grazing intervals resulted in a 
Table 6. Forage mass and percentage of leaves, stems and dead material pre-grazing in mulato grass subjected to rotational stocking strategies during the regrowth

\begin{tabular}{|c|c|c|c|}
\hline \multicolumn{4}{|c|}{ Forage mass $\left(\mathrm{kg} \mathrm{ha}^{-1} \mathrm{DM}\right)$} \\
\hline \multirow{2}{*}{ Time of the year } & \multicolumn{3}{|c|}{ Light interception } \\
\hline & $\mathrm{LI}_{95 \%}$ & $\mathrm{LI}_{\mathrm{Max}}$ & Mean \\
\hline Summer 2008 & $\begin{array}{l}5400 \mathrm{Bc} \\
(198)\end{array}$ & $\begin{array}{l}6870 \mathrm{Ac} \\
(198)\end{array}$ & $\begin{array}{l}6135 \\
(140)\end{array}$ \\
\hline Fall-winter-early spring & $\begin{array}{l}8160 \mathrm{Ba} \\
(305)\end{array}$ & $\begin{array}{l}9300 \mathrm{Aa} \\
(305)\end{array}$ & $\begin{array}{l}8730 \\
(215)\end{array}$ \\
\hline Late spring & $\begin{array}{l}7040 \mathrm{Bb} \\
(335)\end{array}$ & $\begin{array}{l}8990 \text { Aab } \\
(335)\end{array}$ & $\begin{array}{l}8015 \\
(236)\end{array}$ \\
\hline Summer 2009 & $\begin{array}{l}5370 \mathrm{Bc} \\
(240)\end{array}$ & $\begin{array}{l}8320 \mathrm{Ab} \\
(240)\end{array}$ & $\begin{array}{l}6845 \\
(170)\end{array}$ \\
\hline Mean & $\begin{array}{l}5490 \text { B } \\
(108)\end{array}$ & $\begin{array}{l}8370 \mathrm{~A} \\
(108)\end{array}$ & \\
\hline \multicolumn{4}{|l|}{ Leaves $(\%)$} \\
\hline Summer 2008 & $\begin{array}{l}39.5 \\
(1.58)\end{array}$ & $\begin{array}{l}35.1 \\
(1.58)\end{array}$ & $\begin{array}{l}37.3 \mathrm{~b} \\
(0.87)\end{array}$ \\
\hline Fall-winter-early spring & $\begin{array}{l}31.5 \\
(1.13)\end{array}$ & $\begin{array}{l}26.8 \\
(1.13)\end{array}$ & $\begin{array}{l}29.2 \mathrm{c} \\
(0.87)\end{array}$ \\
\hline Late spring & $\begin{array}{l}42.2 \\
(1.09)\end{array}$ & $\begin{array}{l}32.7 \\
(1.09)\end{array}$ & $\begin{array}{l}37.4 \mathrm{~b} \\
(0.87)\end{array}$ \\
\hline Summer 2009 & $\begin{array}{l}42.1 \\
(0.98)\end{array}$ & $\begin{array}{l}38.8 \\
(0.98)\end{array}$ & $\begin{array}{l}40.4 \mathrm{a} \\
(0.87)\end{array}$ \\
\hline Mean & $\begin{array}{l}38.8 \mathrm{a} \\
(0.53) \\
\end{array}$ & $\begin{array}{l}33.4 \mathrm{~b} \\
(0.53)\end{array}$ & \\
\hline \multicolumn{4}{|l|}{ Stems* $(\%)$} \\
\hline Summer 2008 & $\begin{array}{l}27.8 \\
(0.98)\end{array}$ & $\begin{array}{l}29.2 \\
(0.98)\end{array}$ & $\begin{array}{l}28.5 \mathrm{a} \\
(0.69)\end{array}$ \\
\hline Fall-winter-early spring & $\begin{array}{l}21.7 \\
(2.04)\end{array}$ & $\begin{array}{l}26.2 \\
(2.04)\end{array}$ & $\begin{array}{l}23.9 \mathrm{~b} \\
(1.44)\end{array}$ \\
\hline Late spring & $\begin{array}{l}22.9 \\
(1.05)\end{array}$ & $\begin{array}{l}25.3 \\
(1.05)\end{array}$ & $\begin{array}{l}24.1 \mathrm{~b} \\
(0.75)\end{array}$ \\
\hline Summer 2009 & $\begin{array}{l}28.3 \\
(1.00)\end{array}$ & $\begin{array}{l}31.3 \\
(1.00)\end{array}$ & $\begin{array}{l}29.8 \mathrm{a} \\
(0.71)\end{array}$ \\
\hline Mean & $\begin{array}{l}25.2 \mathrm{~b} \\
(0.62)\end{array}$ & $\begin{array}{l}28.0 \mathrm{a} \\
(0.62)\end{array}$ & \\
\hline \multicolumn{4}{|l|}{ Dead material $(\%)$} \\
\hline Summer 2008 & $\begin{array}{l}32.5 \\
(1.61)\end{array}$ & $\begin{array}{l}34.6 \\
(1.61)\end{array}$ & $33.6 \mathrm{c}$ \\
\hline Fall-winter-early spring & $\begin{array}{l}45.7 \\
(1.61)\end{array}$ & $\begin{array}{l}46.3 \\
(1.61)\end{array}$ & $\begin{array}{l}(1.07) \\
46.0 \mathrm{a}\end{array}$ \\
\hline Late spring & $\begin{array}{l}34.8 \\
(1.61)\end{array}$ & $\begin{array}{l}39.8 \\
(1.61)\end{array}$ & $\begin{array}{l}(1.74) \\
37.3 \mathrm{~b}\end{array}$ \\
\hline Summer 2009 & $\begin{array}{l}28.6 \\
(1.61)\end{array}$ & $\begin{array}{l}28.4 \\
(1.61)\end{array}$ & $\begin{array}{l}(0.90) \\
28.5 \mathrm{~d}\end{array}$ \\
\hline Mean & $\begin{array}{l}35.4 \\
(0.78)\end{array}$ & $\begin{array}{l}37.3 \\
(0.78)\end{array}$ & $(0.57)$ \\
\hline
\end{tabular}

Summer 2008 = January 1st to March 31, 2008; fall-winter-early spring = April 1st to November 15, 2008; late spring = November 16 to December 31 , 2008 ; and summer $2009=$ January 1 st to March 31, 2009. The means followed by the same uppercase letter in the rows, and the lowercase letter in the columns do not differ ( $p>0.05$ ). The values in parentheses correspond to the standard error of the mean.

*Analysis conducted on transformed data $(\log 10)$.

greater forage mass at both pre- and post-grazing (Tables 5 and 6); however, this mass showed a greater percentage of stems and dead material. Therefore, the larger forage mass was associated with plant components that are not important from the nutritional, intake, and animal performance perspectives, does not justify the large intervals between the grazing cycles observed for this treatment. In these management conditions, the stems and dead materials were located in upper strata of the sward (Figure 4), imposing physical restrictions to achieving the $15 \mathrm{~cm}$ target height (Laca and Lemaire, 2000) and resulting in post-grazing heights that were considerably above the planned targets (Figure 3). This fact indicates a lower harvesting efficiency (Silveira et al., 2013) of forage with a reduced nutritional value in relation to the $\mathrm{LI}_{95 \%}$ target, which is similar to what was reported by Carnevalli et al. (2006) for mombaça grass. The $\mathrm{LI}_{\mathrm{Max}}$ target also provided a lower light interception postgrazing (Table 4) as a result of the smaller LAI of the pastures (Silveira et al., 2013), which contributed to the increased grazing interval and to the enlarged negative effects on the structure of the forage sward. This fact demonstrates the limitations of the use of excessively long rest periods and emphasizes the importance of controlling the elongation of stems during regrowth as a way to ensure high production of forage with a high nutritive value and harvesting efficiency (Carnevalli et al., 2006; Da Silva et al., 2009). On the other hand, the $\mathrm{LI}_{95 \%}$ target resulted in shorter intervals and a larger number of grazing cycles during the growth season (Tables 1 and 2). Because of the lower time necessary to reach the target of entry of the animals into the paddock, the pre- and 
post-grazing forage masses were lower and had a higher percentage of leaves and a lower percentage of stem and dead material (Tables 5 and 6). Thus, for this management strategy, it was possible to control the elongation of the stems, probably as a consequence of the lower competition for light provided by the more frequent grazing compared with the $\mathrm{LI}_{\mathrm{Max}}$ target. This management strategy results in better growth conditions for the plant stand and a more favourable condition for forage intake by the animals (Hirata et al., 2010). A similar response pattern was reported by Carnevalli et al. (2006) and Da Silva et al. (2009) for mombaça grass and has been observed for other tropical grasses studied in Brazil (e.g., tanzânia, xaraes and marandu grass).

Pastures managed with the $\mathrm{LI}_{95 \%}$ target also showed a smaller foliage angle (leaves placed more horizontally) and a greater LAI post-grazing (Silveira et al., 2013), which enabled greater light interception post-grazing and culminated in faster regrowth. According to Silveira et al. (2013), this management strategy made it possible to achieve greater forage accumulation rates, a higher grazing efficiency, and lower grazing losses, which are desirable when the goal is to produce high forage quality and quantity and to begin this forage arranged in a structure that favours the animals' consumption.

The response of the post-grazing light interception (Table 4) to the post-grazing sward height indicates that there is no difference between the 15 and $20 \mathrm{~cm}$ heights when the pregrazing target of $\mathrm{LI}_{95 \%}$ is utilized, suggesting flexibility of management with this narrow range of residual heights (15 and $20 \mathrm{~cm}$ ). These were maintained stably and always close to what was planned throughout the entire experimental period (Figure 3); they did not cause any negative effect on regrowth, the restoration of leaf area (Silveira et al., 2013), or the pasture structure (Figure 4). This flexibility can be better exploited within the production systems due to the greater or smaller need for a rapid return of the animals to graze to 20 $\mathrm{cm}$ or even for different grazing efficiency targets. Thus, when the objective is greater grazing efficiency, the pasture can be lowered to $15 \mathrm{~cm}$, and when aiming for a greater intake and animal performance, it can be lowered to $20 \mathrm{~cm}$. In this context, the responses of the mulato grass data under the different management strategies over time refers back to the fact that a grazing frequency of $95 \%$ LI provided adequate control in the maintenance of the sward structure.

\section{Materials and Methods}

\section{Location of the experiment}

The experiment was carried out at the Experimental Unit for Forage Plants (UEPF), in an area of the Department of Animal Science of Piracicaba-SP, Brazil (22 ${ }^{\circ} 42^{\prime} \mathrm{S}$ latitude, $47^{\circ} 37^{\prime} \mathrm{W}$ longitude, and $550 \mathrm{~m}$ altitude).

\section{Climatic conditions and water balance during the experimental period}

The climate in Piracicaba city is a Cwa type, according to Köppen's classification, i.e., sub-tropical dry-winter humid mesothermic. Information related to the climatic conditions during the experimental period was obtained from a meteorological station located approximately $500 \mathrm{~m}$ from the experimental area. The monthly mean values for the maximum, average and minimum temperatures and precipitation throughout the experimental period are shown in Figure 1, and the monthly water balance (Thornthwaite and
Mather, 1955), calculated using a $50 \mathrm{~mm}$ AWC, is displayed in Figure 2.

\section{Soil physical and chemical properties}

The relief of the experimental area is classified on a moderately rolling transition between a Mollisol and a Vertisol (USDA Soil Taxonomy) of high fertility (chemical composition of the 0-20 cm layer was (Van Raij et al., 1986): $0.01 \mathrm{M} \mathrm{CaCl} 2 ; \mathrm{pH}=5.5$; organic matter $=38.5 \mathrm{~g} \mathrm{dm}^{-3} ; \mathrm{P}$ (ion-exchange resin) $=82 \mathrm{mg} \mathrm{dm}^{-3} ; \mathrm{Ca}=104 \mathrm{mmolc} \mathrm{dm}^{-3}$; $\mathrm{Mg}=30$ mmolc dm ${ }^{-3}, \mathrm{~K}=6.4 \mathrm{mmolc} \mathrm{dm}^{-3} ; \mathrm{H}+\mathrm{Al}=30$ mmolc $\mathrm{dm}^{-3}$; sum of bases $=140$ mmolc $\mathrm{dm}^{-3}$; cation exchange capacity $=171 \mathrm{mmolc} \mathrm{dm}^{-3}$; and base saturation $=$ $82 \%)$.

\section{Plant material and implementation of the experiment}

The mulato grass (hybrid Brachiaria cv. mulato CIAT 36061) area was established in November 2004 using $5 \mathrm{~kg}$ $\mathrm{ha}^{-1}$ of pure viable seed. Following its establishment, the pastures were rotationally stocked with beef cattle. Before the start of the experimental period, the area was subjected to a levelling and lowering cut (on November 30, 2007) to an average height of $10 \mathrm{~cm}$ using a mower coupled to a tractor. After mowing, $60 \mathrm{~kg} \mathrm{ha}^{-1} \mathrm{~N}$, in the form of ammonium nitrate, was broadcast over the area, and the pastures were monitored from the beginning of its use according to the experimental treatments. In total, including the initial fertilization, $270 \mathrm{~kg} \mathrm{ha}^{-1}$ of $\mathrm{N}$ were applied during the rainy season each year. The experimental period began in January 2008 when the post-grazing height targets were defined.

\section{Treatments, experimental design and traits measured}

The treatments were the factorial combination of two postgrazing targets (15 and $20 \mathrm{~cm}$ in height) and two pre-grazing targets $(95 \%$ and maximum light interception during regrowth: $\mathrm{LI}_{95 \%}$ and $\mathrm{LI}_{\mathrm{Max}}$ ), and they were allocated to 1200 $\mathrm{m}^{2}$ sixteen experimental units arranged in a randomized complete block design. The pasture was grazed by Nellore and Canchim heifers with an average initial body weight of $250 \mathrm{~kg}$, and the number of animals was calculated so that the target post-grazing height would be reached in no longer than $10-12 \mathrm{~h}$ of daytime grazing using the mob grazing technique (Gildersleeve et al., 1987).

The light intercepted by the forage canopy was monitored using a LI-COR LAI 2000 (LI-COR, Lincoln, Nebraska, USA, 1992). The post-grazing measurements were made soon after the animals exited the pasture, and the measurements were made weekly during the regrowth period until $90 \%$ LI was reached. From that point, the LI was measured every two days until the $\mathrm{LI}_{95 \%}$ and $\mathrm{LI}_{\mathrm{Max}}$ were reached. The measurements were taken at two locations per experimental unit (sites representing the average condition of the pastures at the moment of sampling - visual assessment of the forage height and mass). During the pre-experimental phase (December 2007 and January 2008), the maximum LI recorded by the experiment was determined as that in which the values remained unaltered for two consecutive evaluations, which was $99 \%$. The pre- and post-grazing pasture heights were measured concurrently with the LI assessments using a sward stick (Barthram, 1985). One hundred readings were taken along zigzag trajectories defined a priori and used during the entire experimental period for each paddock. 
The forage mass evaluations were performed pre- and postgrazing in the sites representing the average condition of the paddocks at the moment of sampling (visual assessment of the forage height and mass), using $0.90 \times 0.37 \mathrm{~m}\left(0.333 \mathrm{~m}^{2}\right)$ metal frames. Three samples were collected per paddock by cutting the forage at soil level. The harvested material was sub-sampled, subjected to manual separation of the morphological components, including the leaf (leaf blades), stem (leaf sheaths and stem), dead material, and weeds, and dried in a forced-air oven at $65{ }^{\circ} \mathrm{C}$ until it reached a constant mass. Because the percentage of weeds was lower than $2 \%$, the stands were considered pure mulato grass.

The vertical distribution of the morphological components was evaluated pre- and post-grazing during all grazing cycles by utilizing an inclined point quadrat with the pin entering the canopy at an angle of $32.5^{\circ}$ (Warren Wilson, 1960). Touches of leaf (leaf blade), stem (leaf sheath + stem), and dead material components and weeds were recorded, along with the height of occurrence, as the tip of the pin was inserted through the canopy to soil level. The evaluations were always performed on the sites that would represent the average visual condition of the pastures (forage height and mass evaluation) at the time of sampling. A minimum of 100 touches was performed per paddock per evaluation, and the morphological composition of the diverse vertical strata was calculated as a percentage of the total touches performed in each stratum.

\section{Statistical analysis}

The data were grouped according to the seasons of the year based on periods that represented potentially important changes in the response pattern throughout the experimental period (Da Silva et al., 2009). The seasons were: Summer 2008 - January 1st to March 31, 2008; Fall-winter-early spring - April 01 to November 15, 2008; Late spring November 16 to December 31, 2008; and Summer 2009 January 1st to March 31, 2009.

The clustered data were analysed using the PROC MIXED procedure of the $\mathrm{SAS}^{\circledR}$ statistical package (Statistical Analysis System) version 8.2 for Windows ${ }^{\circledR}$. All of the datasets were tested for normality of error distribution and homogeneity of variances. In some cases, it was necessary to transform the data, which was done according to the indication suggested by the $\mathrm{SAS}^{\circledR}$ software. The variancecovariance matrix was chosen using Akaike's Information Criterion (Wolfinger, 1993), and the analysis of variance was performed using a mathematical model containing the random effect of blocks and the fixed effects of the light interception pre-grazing, the post-grazing height, the time of year, and their interactions (Littel et al., 1996). The means of the treatments were estimated using the "LSMEANS" option, and they were compared through a Student's $t$ test at 5\% probability.

\section{Conclusions}

Under rotational grazing, mulato grass should be maintained at a height of $30 \mathrm{~cm}$ pre-grazing and a flexible post-grazing height between 15 and $20 \mathrm{~cm}$. This leads to adequate control of sward structure because this management strategy provides at the same time a good pasture growth, but with important features for maximum forage intake and nutrients by grazing animals.

\section{Acknowledgements}

We would like to thank the CNPq for the sponsorship provided to the first author during the research and the support postgraduate programme of UFV and ESALQ.

\section{References}

Barthram GT (1985) Experimental techniques: the HFRO sward stick. In: Alcock MM (ed) Proceedings of the biennial report of the hill farming research organization. Penicuik, Midlothian, UK. p. 29-30.

Bircham JS, Hodgson J (1983) The influence of sward condition on rates of herbage growth and senescence in mixed swards under continuous stocking management. Grass Forage Sc. 38:323-331.

Carnevalli RA, Da Silva SC, Oliveira AA, Uebele MC, Bueno FO, Hodgson J, Silva GV, Moraes JP (2006) Herbage production and grazing losses in Panicum maximum cv. Mombaça pastures under four grazing managements. Trop Grasslands. 40: 165-176.

Da Silva SC, Carvalho PCF (2005) Foraging behaviour and herbage intake in the favorable tropics/sub-tropics. In: Mcgilloway DA (ed). Grassland: A global resource. Wageningen Academic Publishers, chap 6. Netherlands, England.

Da Silva SC, Bueno AAO, Carnevalli RA, Uebele MC, Bueno FO, Hodgson J, Matthew C, Arnold GC, Morais JPG (2009) Sward structural characteristics and herbage accumulation of panicum maximum cv. mombaça subjected to rotational stocking managements. Sci Agr. 66: 8-19.

Da Silva SC, Sbrissia, A, Pereira, LE (2015) Ecophysiology of $\mathrm{C} 4$ forage grasses-Understanding plant growth for optimising their use and management. Agriculture-London. 5:598-625.

Euclides VPB, Lopes FC, Nascimento Junior D, Da Silva SC, Difante GS, Barbosa RA (2015) Steer performance on Panicum maximum (cv. Mombaça) pastures under two grazing intensities. Anim Prod. 1.DOI: 10.1071/AN14721.

Fonseca L, Mezzalira JC, Bremm C, Filho RSA, Gonda HL, Carvalho PCF (2012) Management targets for maximizing the short-term herbage intake rate of cattle grazing in sorghum bicolor. Livest Sci. 145: 205-211.

Gildersleeve RR, Ocumpaugh WR, Quesenberry KH, Moore JE (1987) Mob-grazing of morphologically different Aeschynomene species. Trop Grasslands. 21: 123-132.

Hirata M, Kunieda E, Tobisa M (2010) Short-term ingestive behaviour of cattle grazing tropical stoloniferous grasses with contrasting growth forms. J Agr Sci. 148: 615-624.

Hodgson J, Maxwell TJ (1981) Grazing research and grazing management. In: Biennial Report of the Hill Farming Research Organization, Penicuik, Midlothian, UK. p. 169188

Laca EA, Lemaire G (2000) Measuring sward structure. In: T'Mannetje L, Jones RM (eds) Field and laboratory methods for grassland and animal production research, New York. p. 103-122.

Li-Cor (1992) Plant canopy analyzer: LAI-2000; operating manual. Lincoln, Nebraska, USA.

Littell RC, Milliken GA, Stroup WW, Wolfinger RD (1996) SAS® system for mixed models. 1rd edn. SAS Institute Inc, Cary. 
Silveira MCT, Da Silva SC, Souza Júnior SJ, Barbero LM, Rodrigues CS, Limão VA, Pena KS, Nascimento Júnior D (2013) Herbage accumulation and grazing losses on mulato grass subjected to strategies of rotational stocking management. Sci Agr. 70: 242-249.

Thornthwaite CW, Mather RJ (1955) The water Balance. Centerton: drexel institute of technology, laboratory of climatology. 104p. (Publications in climatology, v.8, n.1)

USDA Soil taxonomy. United States Department of Agriculture. Official Soil Series Descriptions with series extent mapping capabilities. Available at: http://soils.usda.gov/technical/classification/osd/index.html (Accessed 25 January, 2012).

Van Raij B, Quaggio JA, Silva NM (1986) Extraction of phosphorus, potassium, calcium and magnesium from soils by an ion-exchange resin procedure. Commun Soil Sci Plan. 17: 547-566.

Warren Wilson J (1960) Inclined point quadrat. New Phytol. 58: 92-101.

Wolfinger RD (1993) Covariance structure selection in general mixed models. Commun Stat-Simul C. 22: 10791106. 